\title{
Framework of Soft Skills Infusion Based on Learning Contract Concept in Malaysia Higher Education
}

\author{
Jumali Hj. Selamat ${ }^{1}$, Khaidzir Hj. Ismail ${ }^{1,2}$, Azizan Ahmad ${ }^{1,3}$, Mohd Haither Hussin ${ }^{4} \&$ Salbiah Seliman ${ }^{5}$ \\ ${ }^{1}$ Centre for Learning Accreditation, Universiti Kebangsaan Malaysia, Bangi, Malaysia \\ ${ }^{2}$ School of Psychology and Human Development, Faculty of Social Sciences and Humanities, Universiti \\ Kebangsaan Malaysia, Bangi, Malaysia \\ ${ }^{3}$ Faculty of Science and Technology, Universiti Kebangsaan Malaysia, Bangi, Malaysia \\ ${ }^{4}$ Faculty of Mechanical, Universiti Teknologi MARA, Shah Alam Selangor, Malaysia \\ ${ }^{5}$ Kolej Teknologi Darulnaim, Jalan Padang Golf, Pengkalan Chepa, Kota Bharu, Malaysia \\ Correspondence: Jumali Hj. Selamat, Centre for Learning Accreditation, Universiti Kebangsaan Malaysia, 43600 \\ Bangi, Selangor, Malaysia. E-mail: jumali@ukm.my
}

Received: January 15, 2013 Accepted: March 19, 2013 Online Published: May 14, 2013

doi:10.5539/ass.v9n7p22 URL: http://dx.doi.org/10.5539/ass.v9n7p22

\begin{abstract}
The implementation of co-curriculum via learning contract is a new concept which was first introduced at the National University of Malaysia in the year 2011. The main objective is to complement the existing academic co-curriculum towards developing and produce graduates who not only knowledgeable and skillful but also able to develop a well-rounded balance life. This includes physical, spiritual and intellectual life experience in a variety of contexts and nurturing talent. Among others, it is the intention of the National University of Malaysia to strategically position their approach into soft skills development. This is in line with The Ministry of Higher Education of Malaysia objective to embed training on soft skills into all aspects of learning in the higher learning co-curriculum. This is a concept paper with two goals: 1) to provides the description whose purpose is to give a synopsis of the co-curriculum principles called The Eight Principles and 2) to discuss the use of learning contracts in enhancing soft skills among university students.
\end{abstract}

Keywords: soft skills, learning contract, co-curriculum, Malaysia \& UKM

\section{Introduction}

Malaysian Government will reinforce of both human capital development and promoting the mentality together with the intellectual capacity to enable the country to be at par with other developed nations. To meet this growing demand, The Ministry of Higher Education of Malaysia has taken the initiatives and formally announced that the soft skills is to be introduced and incorporated in the undergraduate syllabus. In addition, there seems to be a much widespread condemnation of the industry that most employers found out that generally graduates are academically proficient; however, they are lacked of soft skills.

Soft skills have been recognized as the highly critical skills in the current global job market, especially in a fast-moving era of technology. It also commands high percentage of budgets on training in most organizations (Crosbie, 2005). In the National University of Malaysia, the top management has taken a huge initiative to successfully develop a strategic plan in an attempt to equip and train students the soft skills and personality development. This is to meet primarily the considerable challenges of the workplace and to produce graduates with diverse abilities. The Vice Chancellor of the National University of Malaysia has coined the idea to implement credited co-curriculum programs based on learning contract. The co-curriculum activities will complement the academic curriculum in order to generate and create holistic graduates physically, emotionally, spiritually and intellectually through living experiences in many different talents generating contexts.

\section{Learning Contract}

There are plethora of literature review regarding learning contract (Boak \& Mac Stephenson, 1987(a); Boak \& Mac Stephenson, 1987(b); Knowles, 1987; Prideaux \& Ford, 1988) and essentially consists of four basic key that are interrelated: objectives, learning plans, implementation and evaluation. 
In the context of the work environment, learning contract is principally a written agreement between a manager, his or her trainee, and a trainer/tutor clearly detailing what the trainee is going to implicitly learn and where applicable how they are going to apply their learning in the workplace. According to Knowles (1987), he defined learning contract as "a means for helping learners' structure learning project's systematically-for involving them actively in planning their own learning".

The use of learning contract has attracted great interest and recognition in higher education (Mike and John, 2002). Mike and John (2002) describe learning contract is somewhat a mutual agreement between students and academic staff on negotiated term pertaining to the type and amount of study to be undertaken. It also includes the type and amount of assessment resulting from the study. They further pointed out that the contracts are "not a contract in the legal sense but indicates a commitment of the parties to study or learning involved"(Mike \& John, 2002)

\section{The Learning Contract Concepts}

Conceptually, the co-curriculum is to generate and create holistic graduates physically, emotionally, spiritually and intellectually through living experiences in many different talents generating contexts. There are eight (08) principles of the co-curriculum which includes honor, student-driven, flexible, enjoyable, experiential learning, authentic, total learning experience and soft-skills.

In the context of National University of Malaysia, the co-curriculum concept of learning contract act as a guide to monitor, track and direct the student's learning and the academic staff teaching. Basically, it is a joint process which includes identifying the process and content of student learning. Thus, it creates an opportunity for both student and the instructor to engage in a discussion on individual learning, expectations and determine supervisory sessions.

Through time, the co-curricular activities aim to encouraged student in performing multi-task and to take on new challenges on a rapidly changing environment on a day-to-day basis. In addition, it is to cultivate self-discipline, promote fully independent learning and develop personal and social skills. Given the practical life skills, they will stand in good stead on their way to their next destination in life wherever that may be. It is with high hope and great expectation of the National University of Malaysia that by linking the soft skills into the learning contract will enable graduate students to engage in changing in their behavior. This includes changes in knowledge, skills and attitudes.

The idea behind this concept is to be able to function and create a learning environment that able to ensure not only in terms of academic learning quality but also student integrity. It is found that assessment of student achievement based on specified grade where the criteria were set by the instructor (Hardigan, 1994) and written exam orientation together with passive learning process (Hussain et al. 2008) is consider a hindrance to an effective learning process and restraint the development of soft skills. Central to the underlying learning approach in the above concept is the student-driven, with the main aim is for the student to acquire knowledge and enhance their soft skills.

The concept allows students to involve in the activity or program of their choice that they are able to excel, improve and sharpen their talent in their interest area. In addition, they will able to nurture their skills in a flexible learning and enjoyable one. Their participation and appreciation through experiential learning in the development of activity has to be authentic which in turn make the co-curriculum a complete total learning experience. Students are encouraged to constantly endeavor if they are to succeed, with trust and honor. 


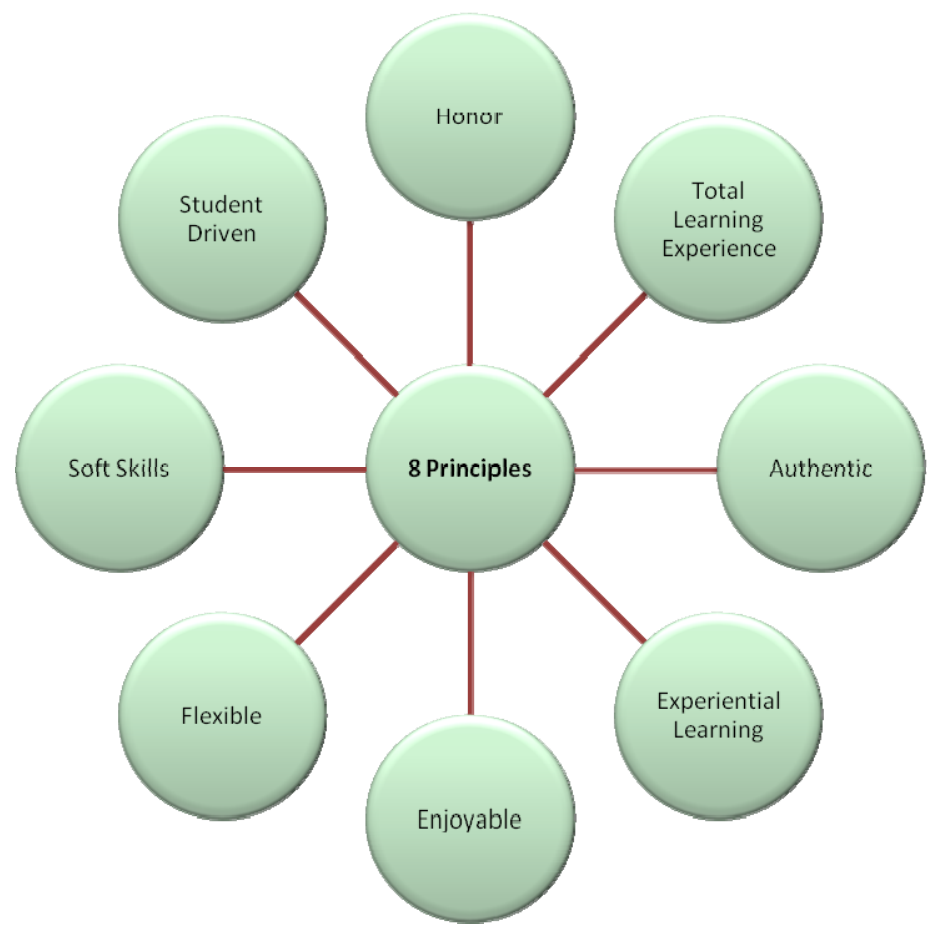

Figure 1. Eight principles of learning contract

\subsection{Honor}

In the era of technological global society, students not only need to develop the knowledge skills and values they require to become productive but also be an honorable student. Honorable student is a student of honesty and integrity and these two words are inseparable (Scanati, 1997). According to Covey (1989) in his book, he observed that "Integrity includes but goes beyond honesty.

Honesty is telling the truth - in other words, conforming our words to reality. Integrity is conforming reality to our words - in other words, keeping promises". The concept of honor puts forward in this framework incorporates not only honesty and integrity but also include honorable, reliable and responsible. This holistic approach covers from the initiation up to completion of the activity. To achieve this goal a close supervision is carried out on a regular basis and supervisor are expected to internalize the concept of honor.

\subsection{Student-Driven}

Learning requires students to do meaningful learning activities and think about what they are doing (Prince, 2004). According to Hiemstra (1994), "self-directed learning is seen as any study form in which individuals have primary responsibility for planning, implementing, and even evaluating the effort". His work is being further shared by Wilcox (1996) and she defined self-directed learning as a process of learning that provides independent learners to take full responsibility, initiative and evaluate their own learning efforts. Chang (2007) observed that the self-directed learning readiness is somewhat a learning behavior and this is one type of behavior that allows students to continue learning on their own initiative.

In this concept, the central focus is largely student-driven according to individual preference, and it is where students own the learning. They can share a common interest among student member to produce a product, performance, or targeted services. In addition, they are allowed to choose the appropriate supervisor for their project, they wish to participate. Student-driven also provides opportunities to develop multiple talents. Aspect of innovation is equally important. The students are encouraged, develop, enables, and promotes the entrepreneurial and innovative talents who can literally transform their future.

In addition, the self-driven student activities aimed at acquiring knowledge and soft-skills. These activities or projects are carried out at different learning centers chosen by the students themselves entirely depending on their interests and inclinations as to enhance their talents and skills in a flexible and enjoyable learning environment. The students' active involvement and apprehension through experiential learning and authentic activities makes the co-curriculum a compliment to the total learning experience based upon the values of trust 
and honor.

\subsection{Flexible Learning}

There is no clear definition of flexible learning (Murray et al. 2004). However, flexible learning allows the learners to have control time, place and processes in their study (Race, 1998). The concept of flexible learning in the context of the National University of Malaysia that was put forward in the learning contract framework is to empower students and create a sense of stewardship by developing action and decision makings. In order to promote the goals, the curriculum is widely designed with sufficient flexibility to allow students to reach its potential. It requires a more flexible approach to program and curriculum design so that the partnership develops between the supervisor and students to determine the execution of the co-curriculum activity.

\subsection{Enjoyable}

Meyers and Jones (1993) state, active learning derived from two assumptions: (1) the fact that learning is an activity that is active and (2) different students have different learning styles. Alleviating active learning will enable students to learn new knowledge and skills in a way that is both challenging and enjoyable (Baid and Lambert, 2010). Pursuant to Knowles et al. (2005) in their research work, students will be more interested and motivated to learn if they attended enjoyable lectures.

The co-curriculum concept in the learning contract eight principles is embedded with a socially-rich and enjoyable experience. Students have the freedom to govern themselves, think creatively and independently. In addition, they can select the subject of their project, expand them and plan their time. The aim is to help graduates and provides them with a positive and enjoyable learning experience. It is purposive to generate considerable interest in the curriculum and to adequately prepare students for their foreseeable future careers.

\subsection{Experiential Learning}

Experiential learning promotes the concept of learning experience where the learner is directly involved with the actual environment being studied. Dewey (1938) simplified the concept of experiential education which claims that there is an organic connection between education and personal experience. Kolb (1984) argues that experiential learning is founded on the idea that learning is grounded in experience.

The experiential learning put forward in the eight principles of learning contract shown in Figure 1.0 is to promote and inculcate self-confidence and self-development. Programs undertaken by the students involve intense exposure with real-life situation and can accumulate profound knowledge through time. Their practical experience and knowledge will provide them the advantage of being fully prepared for intellectually challenging careers.

\subsection{Authentic}

Most university graduates enter the working world without sufficient basic familiarity with the environment that they may be engaged with. Among others, they may face greater challenges of dealing with highly flawed information, enormously complex assignments, and linking abstract theory to actual conditions. To overcome such a precarious situation, it is essential to introduce authentic activities to help students in understanding the complexity of the world and prepare them for real life.

Newman and Wehlage (1993) describe authentic activities are real-world tasks that an individual can expect to encounter on the job. According to Ormrod (2008), he defined authentic activities as tasks identical to what a student will engage in the outside world. The activities attempted by the students will prepare them for activities that somewhat resemble a practical activity that they might commonly encounter when in the work force. Having different activities incorporated within the schedule curriculum, it helps students to form a mental connection between the information and knowledge they have acquired in the classroom setting to the real-life activity (Ormrod, 2008).

In the eight principle concept, the authentic activities are those activities that provide the students with learning experiences which enables them to develop the knowledge and necessary skills. The students must successfully be able to transfer those knowledge and skills from one idea to real-life situations.

\subsection{Total Learning Experience}

Learning takes place in many different settings and levels simultaneously. The setting can be both inside and outside classroom. The concept of total learning experience shown in figure 1.0 is to produce students not only academically equipped to meet the real challenges but also be responsible and contribute to the society. It is also intended that the college is committed to produce graduates who will realize their full potentials and are confidence to lead their life's students' total learning experience through which students will gain skills and a 
broad range of knowledge. In addition, it is intended to produce students that capable of thinking critically and who will be lifelong learners.

\subsection{Soft Skills}

Soft skills, also known as "people skills" is not easy to quantify and it is sometimes described as intangibles (Boak and Mac Stephenson, 1987a). As reported by Bennett et.al (1999) the soft skills are the "skills that support any discipline (generic), and which can be transferred to a range of contexts, in higher education or the workplace". Although there are no clear and specific skills that are listed as "Soft" skills (Crobie, 2005) ; however, the Ministry of Higher Education Malaysia (MOHE) has taken the initiatives to incorporate the aspects of generic skills to soft skills. This includes non-academic skills such as leadership, teamwork, communication, and lifelong learning.

As all these skills need to be embedded in the syllabus taught at an Institute of Higher Learning (Knowles, 2005), the concept of soft skills put forward in the learning contract framework includes leadership, teamwork, communication, and lifelong learning.

Ministry of Higher Education Malaysia developed a framework as shown in figure 2.0. This framework suggests the possible approach that should be undertaken in implementing soft skills, however, higher institutions are allowed to make variations and additions which deem fit for the benefit of the students. It shall be undertaken with a view to improve the students' skills. The soft skill designated by the MOHE that are required to be included in the degree programs consists of seven skills as follows:
1) Communication Skills in English
2) Critical Thinking and Problem-Solving Skills
3) Team-Working Skills
4) Lifelong Learning and Information Management Skills
5) Entrepreneurial Skills
6) Moral and Professional Ethics
7) Leadership Skills

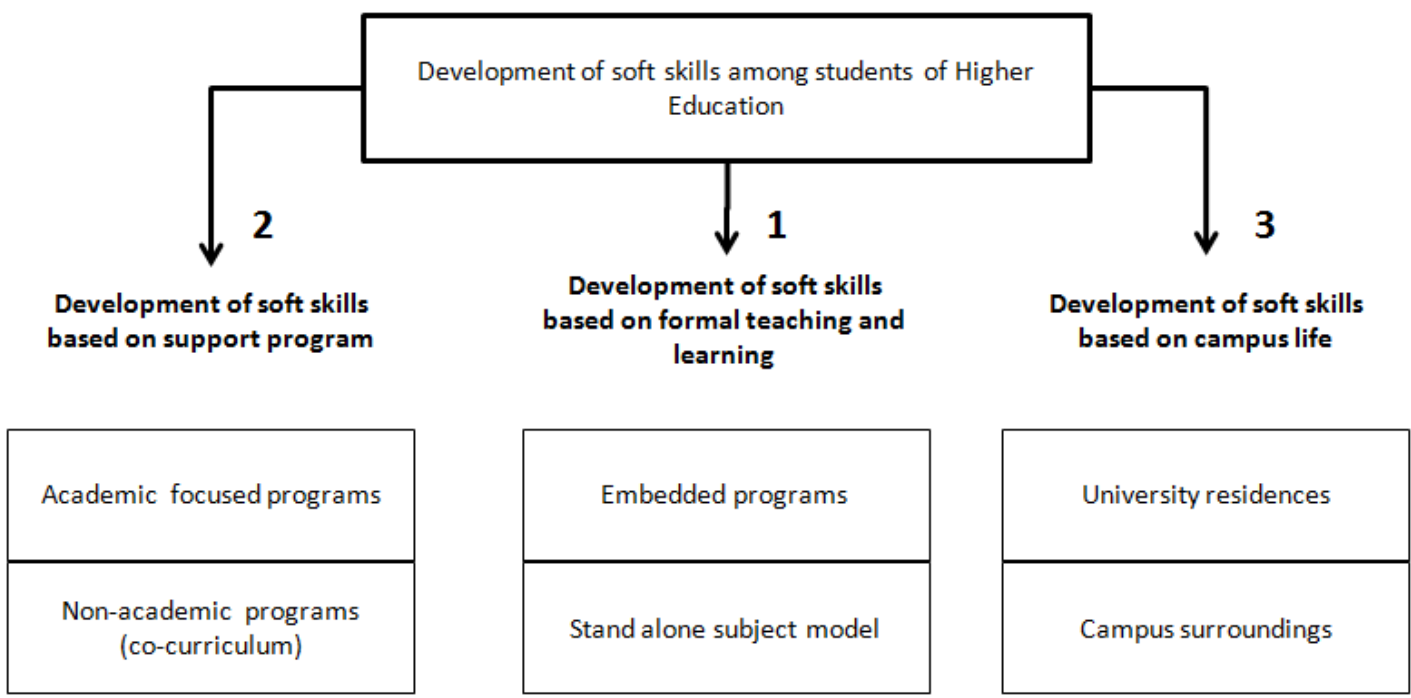

Figure 2. Model for implementation of soft skills in Institute of Higher Learning

Source: Ministry of Higher Education Malaysia (2006)

In the context of the National University of Malaysia soft skills are developed indirectly through active support programs such as co-curricular activities. Activities such as these are non-academic in nature, but indirectly will be able to assist students in gradually developing their personality and character.

\section{Conclusion}

It has been widely known that numerous countries have explicitly acknowledged that higher education has not met the growing expectations of employers (Leckey and McGuigan, 1997; Bennett et al. 1999; Kember et al. 
2007). In Malaysia context, the principal issue is about marketability/employability of graduates from the public universities (Koo, Pang and Fadhil, 2009) which tends to lose out to another graduates of private universities in terms of employment in the domestic competitive marketplace. Among others, the one leading issue which is high on the agenda of the Malaysian Government is to develop strategies and build formal curriculum soft skills. The objective is to grow and generate graduate with the right balance of diverse abilities.

To address the nation's aspiration pertaining to the above matter the National University of Malaysia has taken a responsive approach to develop the eight principles of a learning contract. The aim is to produce competent graduates equip with the appropriate soft skills.

\section{References}

Baid, H., \& Lambert, N. (2010). Enjoyable learning: The role of humour, games, and fun activities in nursing and midwifery education. Nurse Education Today, 30(6), 548-552. http://dx.doi.org/10.1016/j.nedt.2009.11.007

Bennet, N., Dunne, E., \& Carre, C. (1999). Pattern of core and generic skill provision in higher education. Higher Education, 53, 71-93. http://dx.doi.org/10.1023/A:1003451727126

Boak, G., \& Stephenson, M. M. (1987a). Management Learning Contracts: From Theory to Practice, Part 1 -Theory. Journal of European Industrial Training, 11(4), 4-6. http://dx.doi.org/10.1108/eb002226

Boak, G., \& Stephenson, M. M. (1987b). Management Learning Contracts: From Theory to Practice, Part II Practice. Journal of European Industrial Training, 11(6), 17-20. http://dx.doi.org/10.1108/eb014240

Chang, C. C. (2007). Evaluating the effects of comtetency-based web learning on self-directed learning aptitudes. The Journal of Computers in Mathematics and Science Teaching, 26(3), 197.

Covey, S. R. (1989). The 7 habits of highly effective people. New York, Fireside.

Crobie, R. (2005). Learning the soft skills of leadership. Industrial and Commercial Training, 37(1), 45-51. http://dx.doi.org/10.1108/00197850510576484

Dewey, J. (1938). Experience and Education. New York, Collier.

Hardigan, P. (1994). Investigation of learning contracts in pharmaceutical education. American Journal of Pharmaceutical Education, 58, 386-390.

Hiemstra, R. (1994). Self-directed learning. The International Encyclopedia of Education T. H. T. N. Postlewaite. Oxford, Pergamon Press.

Hussain, O., Bahannuddin, M. S., Dawilah, A. E. S. M., \& Abdullah, S. (2008). Pelaksanaan Pendekatan Pembelajaran Berasaskan Pengalaman (PBM dan PBMBP) Bagi Meningkatkan Kemahiran Insaniah Pelajar. Journal of Human Capital Development, 1(1), 61-73.

Kember, D., Leung, D. Y. P., \& Ma, R. S. F. (2007). Characterising learning environment capable of nurturing generic capabilities in higher education. Research in Higher Education, 48, 609-631. http://dx.doi.org/10.1007/s11162-006-9037-0

Knowles, M. S. (1987). Enhancing HRD with Contract Learning. Training and Development Journal, 41(3).

Knowles, M. S., Holton, E. F., \& Swanson, R. A. (2005). The Adult Learner. Burlington, MA, Elsevier.

Kolb, D. A. (1984). Experiential learning: experience as the source of learning and development. Prentice Hall.

Koo, Y. L., Pang, V., \& Fadhil, M. (2009). Employer perceptions on graduate literacies in higher education in relation to the workplace. In English for specific purposes World. Retrieved from http://www.esp-world.info/Articles_20/DOC/Koo_vp_employer_Journal18Oct09.pdf

Leckey, J. F., \& McGuigan, M. A. (1997). Right tracks-wrong rails: The development of generic skills in higher education. Research in Higher Education, 38(3), 365-378. http://dx.doi.org/10.1023/A:1024902207836

Malaysia, M. O. H. E. (2006). Development of soft skills for Institutions of Higher Learning. University Putra Malaysia.

Meyers, C., \& Jones, T. (1993). Promoting active learning: Strategies for the college classroom. San Francisco, CA, Jossey-Bass.

Mike, L., \& John, S. (Eds.). (2002). Using Learning Contracts in Higher Education. London, Routledge.

Murray, P. E., Donohoe, S., \& Goodhew, S. (2004). Flexible learning in construction education: a building pathology case study. Structural Survey, 22(5), 242-250. http://dx.doi.org/10.1108/02630800410571553 
Newmann, F. M., \& Wehlage, G. (1993). Five standards of authentic instruction. Educational Leadership, 55(2), $72-75$.

Ormrod, J. E. (2008). Educational psychology, Developing learners. Upper Saddle River, NJ, Pearson Prentice Hall.

Prideaux, G., \& Ford, J. E. (1988). Management Development: Competencies, Contracts, Teams and Work Based Learning: Part1. Journal of Management Development, 7(1), 56-68. http://dx.doi.org/10.1108/eb051666

Prince, M. (2004). Does active learning work? A review of the research. Journal of Engineering Education, 93(3), 223-231. http://dx.doi.org/10.1002/j.2168-9830.2004.tb00809.x

Race, P. (1998). 500 Tips for Open and Flexible Learning. London, Kogan Page.

Scarnati, J. T. (1997). Beyond technical competence: honesty and integrity. Career Development International, 2(1), 24-27. http://dx.doi.org/10.1108/13620439710157452

Wilcox, S. (1996). Fostering self-directed learning by undereducated adults. Studies in Higher Education, 21(2), 165-176. http://dx.doi.org/10.1080/03075079612331381338

\section{Copyrights}

Copyright for this article is retained by the author(s), with first publication rights granted to the journal.

This is an open-access article distributed under the terms and conditions of the Creative Commons Attribution license (http://creativecommons.org/licenses/by/3.0/). 